On Tuesday evening, 7 April, a number of French colleagues were welcomed to meet members of the Executive Council at a reception given by the Chairman at the offices of Niger-France. On Wednesday morning, 8 April, some recent films made by francophone ethnographers were presented at the Musée de l'Homme by Dr. Jean Rouch.

\title{
Grants for African Studies (U.S.A.)
}

THE Joint Committee on African Studies, and the American Council of Learned Societies have awarded the following grants for research relating to Africa :

Professor Robert H. Bates (California Institute of Technology): an ecological analysis of the relations between modernization, political participation, and opposition voting in Zambia.

Professor George E. Brooks, Jr. (Indiana): the economic and social history of Portuguese Guinea and the Cape Verde Islands, c. I750-1880.

Professor James Duffy (Brandeis) : labour in Portuguese Africa in the twentieth century and a critical analysis of the influence of David Livingstone on Africa.

John D. Esseks (North Illinois) : the efforts of the Ghanaian Government to reduce foreign control of its resources, $1957-69$.

Barbara C. Lewis (Rutgers): the Transporters Association of the Ivory Coast; voluntary association among women engaged in petty trade.

Wyatt MacGaffey (Haverford College): the use of medical services in Matadi (Democratic Republic of Congo), folk categorization of illness, and the relation of schizoid behaviour to conflicting definitions of social roles.

Professor Horace M. Miner (Michigan): the ecology of change among the Hausa of the Anchau Corridor in Zaria Emirate.

Professor Anthony Oberschall (Yale): the relationship between social structure and innovation in entrepreneurial behaviour in Zambia.

Professor Boniface I. Obichere (University of California, Los Angeles): slavery in the precolonial kingdoms of Ashanti and Dahomey.

\section{Les Sciences Humaines au Centre de Lomé (Togo) de l'Office de la Recherche Scientifique et Technique Outre-Mer (ORSTOM)}

DepuIs le dernier trimestre de 1968 les sciences humaines sont en expansion au Centre ORSTOM de Lomé, B.P. 375, Lomé, Togo: l'effectif, qui était d'un ou deux chercheurs depuis la création du Centre en I950, s'élève au ier Janvier I970 à trois sociologues et deux géographes, et un autre sociologue est attendu.

Les travaux sont orientés dans deux directions: D'une part, les études sur les structures agraires, les problèmes fonciers, les migrations, la 'colonisation' des terres neuves, menées par des sociologues et des géographes travaillant seuls ou en équipe interdisciplinaire. D'autre part les recherches portant sur les problèmes du travail industriel.

La 'colonisation' des terres neuves du Centre du Togo par les populations Kabrè et Losso, originaires du Nord du pays, a été étudiée par B. Lucien-Brun, géographe, en 1966 et 1967 . Il poursuit actuellement, en France, le dépouillement et la rédaction des résultats de ses enquêtes et a publié une carte du peuplement des zônes d'immigration agricole Kabrè et Losso; il a aussi dressé une carte des densités de population du Togo d'après le recensement général de la population de 1958-60.

A. Othily, sociologue, a effectué en 1966 une étude monographique sur un village de la lagune. Ce travail a fait l'objet d'un rapport multigraphié. Il a entrepris depuis des travaux de bibliographie dont la mise au point se poursuit en France. Il s'est également occupé de recherches sur l'histoire des communautés villageoises du Sud-Est. Ces travaux ont fait 